\title{
Nutritional Status and Indigenous Mycorrhizal Infection of Berseem Clover and Barley Fertilized with Poultry Litter and Compost in an Organic Farming System
}

\author{
Hala H. Badry ${ }^{1}$, Heba S. A. Salama ${ }^{2}$ and Ahmed Ramadan ${ }^{3}$
}

\begin{abstract}
Organic farming is an agricultural system that is receiving increased attention in forage crop production. The incorporation of composts and manures from different animal and plant sources into forage production systems would positively affect forage yield and quality through enhancing the nutritional status of the plant. Field trials were carried out at SEKEM organic farm, in Egypt, during the winter seasons of 2012 and 2013. Main aim was to study the effect of application of compost and poultry litter on shoot fresh and dry weights $\left(g\right.$ plant $\left.^{-1}\right)$, nitrogen (N) and phosphorous (P) concentration (\%) and uptake (g plant $^{-1}$ ) of barley and berseem clover, as well as to examine the variation in root mycorrhizal infection under the organic farming system. Results revealed that the tested forage crops responded differently to the applied amendments. When fertilized with compost, barley produced the highest fresh and dry weights, amounting to 99.67 and 17.37 (g plant $\left.{ }^{-1}\right)$, respectively. Compost application also enhanced $P$ concentration $(0.36 \%)$ and uptake (6.25 g plant $^{-1}$ ) and $N$ uptake (35.61 g plant $\left.^{-1}\right)$ in barley plants compared to poultry litter and control (no fertilization). On the other hand, berseem clover recorded its highest fresh and dry weights with the application of poultry litter, 2.5 and 0.27 ( g plant $\left.^{-1}\right)$, respectively. In addition, application of poultry litter significantly enhanced $\mathrm{P}\left(0.08 \mathrm{~g} \mathrm{plant}^{-1}\right)$ and $\mathrm{N}\left(0.84 \mathrm{~g} \mathrm{plant}^{-1}\right)$ uptake in beseem clover, while $P$ and $\mathbf{N}$ concentrations were similar under compost and poultry litter application. Although root mycorrhizal infection was detected in both crops, that were organically fertilized, its percentage didn't vary significantly among the tested organic amendments. The current results suggest that, under the organic farming system, fertilizing barley with compost and berseem clover with poultry litter would improve yield and quality of the end fodder through improving the nutrients' uptake and concentration in the plants.
\end{abstract}

Key words: Berseem clover, barley, organic farming, forage, mycorrhiza.

\section{INTRODUCTION}

A major limiting factor for livestock production in Egypt is the shortage of quality feed. In order to solve this problem, productivity from both forage crops and livestock should be enhanced. This could be achieved through efficient use of all the available resources and adopting effective farming systems. Organic farming is an agricultural system that is efficient in enhancing natural biological processes and, thus, maintaining and improving the land use efficiency and the productivity and quality of the final product. It is an agricultural philosophy and a farm management system that aims at promoting plant, animal and human health (Gupta, 2007). It was reported that incorporating composts and manures from different animal and plant sources into forage production systems positively affect soil productivity and physical properties (Edmeades, 2003 and Lynch et al., 2005), which will be reflected on forage crop yield and quality (Salama, 2015). On the other hand, the improper use of animal and poultry wastes would have adverse ecological impacts causing soil, air, and water pollution (Newton et al., 2003 and Zhang et al., 2009). It is, therefore, recommended to utilize compost and poultry litter in crop production, accompanied with proper agronomic management practices. This would help closing the nutrient cycle by the utilization of nitrogen produced from dairy farms again in forage crop production (Lithourgidis, et al., 2007). Therefore, linking forage production with manure utilization is an environmentally effective approach for addressing problems associated with intensive dairy production systems. Nonetheless, cultivation depending on the use of organic fertilizers in cropping management reduces the input of chemical fertilizers. Manure appropriately applied to growing crops allows the opportunity to eliminate the nitrogen fertilizer input for crop production (Giovanni et al., 2011). The application of compost or poultry litter to forage crop production systems reported significant effects on the resulting forage yield and quality through manipulating its nutritional status. Significant effects of organic fertilizers' scheme on phosphorous (P) and nitrogen $(\mathrm{N})$ concentration and uptake were reported for

\footnotetext{
${ }^{1}$ Soil and Water Science Department, Faculty of Agriculture,

Alexandria University, Alexandria, Egypt.

${ }^{2}$ Crop Science Department, Faculty of Agriculture, Alexandria University, Alexandria, Egypt.

${ }^{3}$ General Authority of the Executive Device for Soil Improvement Projects, Ministry of Agriculture, Egypt

${ }^{2}$ Corresponding author: heba1942001@yahoo.com

Received December 12, 2016, Accepted December 27, 2016
} 
several forage species. It was reported that the application of poultry litter increased the $\mathrm{N}$ and $\mathrm{P}$ uptake in tall fescue and bluegrass pasture (Lucero et al. 1995) as well as the $\mathrm{N}$ and $\mathrm{P}$ concentrations in tall fescue plant tissues (Kingery et al. 1993). Moreover, Muir et al. (2001) observed an increase in forage P concentration of kenaf, lablab, cowpea and sunflowers by around $18.8 \%$ with compost application. In Egypt as well as in many countries in the world, the most used forages belong to the two botanical families: Gramineae (Poaceae) and Leguminosae (Fabaceae) which are grown to support successive cuttings for dry matter production throughout their vegetative cycle (Tessem et al., 2010). Berseem clover (Trifolium alexandrinum L.) is the most common forage leguminous crop grown in Egypt in the winter season. It is characterized by its high protein content (De Santis et al., 2004), and ability to improve soil fertility through the symbiotic fixation of atmospheric nitrogen (Mezni and Sifi, 1995). Berseem clover is also tolerant to the low winter temperatures and have a very good regrowth ability (Mezni et al., 2013). On the other hand, barley (Hordeum vulgare L.) is among the important grasses in the winter forage production system in Egypt. It is characterized by its high tolerance to salinity, drought and its high productivity under adverse environmental conditions compared to other small grain cereals (Alazmani, 2014). It, therefore, serves as a major animal fodder. Significant variations in fodder yield and quality of forage grasses and legumes and their mixtures as affected by poultry litter and compost application, were documented (Salama, 2015), however, the effect of the tested organic fertilizers on the nutritional status of the plant, in terms of micro/macro nutrients' uptake \& concentration was not investigated. Nonetheless, it is expected that forage legumes (represented by berseem clover) and forage grasses (represented by barley) would respond differently to the application of organic fertilizers under the organic farming system, with respect to their nutritional status, in terms of fresh and dry weights, nutrients' concentration and uptake.
A key component of soil microbiota are arbuscular mycorrhiza (AM) fungi. They are obligate symbionts that are not host specific (Bonfant-Fasolo, 1987), but form obligate symbiotic associations with the roots and other underground parts of most plants. Their association with plant roots score several advantages, amongst is their ability to improve the growth of plants by providing higher absorptive surface compared with root hair, and thus help in the absorption of relatively immobile soil nutrients, especially phosphorous (Bagyaraj,1992 and Oehl et al., 2004). Beside their natural presence in the soil, AM fungi have great potential for use as bio-fertilizer in agriculture (Trivedi, 2007). Previous studies reported significant variations in naturally occurring soil mycorrhizal communities between conventional and organic farming systems (Oehl et al., 2004).

The current study was, thus, designed to study the effect of application of organic fertilizers, in the form of poultry litter or compost on shoot fresh and dry weights, $\mathrm{N}$ and $\mathrm{P}$ concentration and uptake of barley and berseem clover, as well as to examine the variation in root mycorrhizal infection under the organic farming system.

\section{MATERIALS AND METHODS}

\section{Experimental site, design and treatments:}

Field trials were carried out during the winter seasons of 2012 and 2013 at SEKEM organic farm. The farm is located near the town of Belbeis, 60 kilometres north-east of Cairo, Egypt, and characterized by its semi-desert land. Some chemical characteristics of the experimental soil are presented in Table (1).

Two 2-year (2012 and 2013) field trials were laid out in a randomized complete block design (RCBD) with three replicates and aimed at evaluating the effect of organic fertilizer application, in the form of poultry litter or compost, in addition to a control treatment (without fertilization) on the nutritional status of two prominent forage crop species in Egypt, namely; berseem clover (Trifolium alexandrinum L.), cultivar Helaly (first trial) and barley (Hordeum vulgare L.), cultivar Siko (Second trial).

\section{Table 1. Chemical characteristics of the experimental soil}

\begin{tabular}{|c|c|c|c|c|c|c|c|}
\hline $\begin{array}{c}\text { EC } \\
\left(\mathbf{d S m}^{-1}\right)\end{array}$ & pH & $\begin{array}{c}\mathrm{CaCO}_{3} \\
(\%)\end{array}$ & $\begin{array}{c}\text { Organic } \\
\text { Matter (\%) }\end{array}$ & $\begin{array}{c}\mathrm{N} \\
\left(\mathrm{kg} \mathrm{h}^{-1}\right)\end{array}$ & $\begin{array}{c}\mathbf{P} \\
\left(\operatorname{kg~h}^{-1}\right)\end{array}$ & $\begin{array}{c}\mathrm{K} \\
\left(\mathrm{kg} \mathrm{h}^{-1}\right)\end{array}$ & $\begin{array}{c}\text { CEC } \\
\left(\mathrm{m} \mathrm{mole} \mathrm{kg}^{-1}\right)\end{array}$ \\
\hline 3.3 & 7.8 & 5.5 & 0.7 & 2250 & 211 & 1065 & 71 \\
\hline
\end{tabular}

\begin{tabular}{|c|c|c|c|c|c|c|c|c|c|c|c|c|}
\hline $\begin{array}{l}\text { Organic } \\
\text { Fertilizer }\end{array}$ & $\begin{array}{l}\text { EC } \\
(1: 10) \\
d^{S} ~ m^{-1} \\
\end{array}$ & $\begin{array}{r}\text { pH } \\
(1: 10)\end{array}$ & $\begin{array}{r}\text { Bulk } \\
\text { density } \\
\mathrm{kg} \mathrm{m}^{-3} \\
\end{array}$ & $\begin{array}{r}\text { Moisture } \\
\text { content } \\
(\%) \\
\end{array}$ & $\begin{array}{r}\text { Organic } \\
\text { carbon } \\
(\%) \\
\end{array}$ & $\begin{array}{r}\text { Organic } \\
\text { Matter } \\
(\%) \\
\end{array}$ & $\mathrm{C} / \mathrm{N}$ & $\begin{array}{r}\mathrm{NO}_{3}-\mathrm{N} \\
\left(\mathrm{mg} \mathrm{kg}^{-1}\right)\end{array}$ & $\begin{array}{l}\text { VH4-N } \\
\mathrm{mg} \mathrm{kg}^{-1} \text { ) }\end{array}$ & $\begin{array}{l}\text { Total } \\
\text { N }(\%)\end{array}$ & $\begin{array}{l}\text { Total } \\
\text { P (\%) }\end{array}$ & $\begin{array}{l}\text { Total } \\
\text { K(\%) }\end{array}$ \\
\hline Compost & 6.16 & 8.55 & 690 & 35 & 26.72 & 46.07 & 14.21 & 98 & 785 & 1.88 & 0.58 & 1.06 \\
\hline $\begin{array}{l}\text { Poultry } \\
\text { litter }\end{array}$ & 8.76 & 8.23 & 550 & 19.8 & 31.35 & 54.05 & 10.05 & 365 & 3225 & 3.12 & 1.42 & 2.51 \\
\hline
\end{tabular}


The compost was prepared as a mixture of $30 \%$ cow manure, $5 \%$ chicken manure, $20 \%$ coffee ground, $10 \%$ loam (Tamia), $20 \%$ rice straw, and $15 \%$ green plant material. All the constituents were put in layers to form a heap $2 \mathrm{~m}$ wide and $1.8 \mathrm{~m}$ high. A starter bacteria was then added, in addition to the needed appropriate amount of water. The temperature and $\mathrm{CO}_{2}$ content of the heap were controlled every day, and if temperature was more than $60^{\circ} \mathrm{C}$ or the $\mathrm{CO}_{2}$ content was more than $13 \%$ the compost heap was turned with a compost turner. According to this procedure, the compost pile was ready for use after approximately 10 weeks from the beginning of the composting process. Concerning the poultry litter, it was mainly made up from a mixture of bed, that was formed from dust wood or rice husks, and remnants of poultry feed and craps that was unloaded, piled and applied fresh to the soil without composting. The physicochemical characteristics of the used compost and poultry litter are presented in Table (2).

\section{Management and sampling:}

The experimental plots of both experiments were sown on mid-October in 2012 and 2013. The plot size was $9 \mathrm{~m}^{2}$. The tested crops were drilled with the recommended seeding rates by the Egyptian ministry of agriculture, amounting to $40 \mathrm{~kg} \mathrm{ha}^{-1}$ for berseem clover and $100 \mathrm{~kg} \mathrm{ha}^{-1}$ for barley. Similar cultural practices were applied to all experimental plots, i.e. fertilization and harvesting took place at the same intervals in both growing season. Organic fertilizers were added at the rate of 8 ton ha ${ }^{-1}$. Weeds were hand-removed from plots and no serious incidence of insects or diseases was observed. Biological $\mathrm{N}$ fixation was encouraged by inoculating berseem clover seeds with Rhizobium trifolii, commercially produced by the Ministry of Agriculture, Egypt.

Samples were taken at 55 and 45 days after sowing (DAS) in case of berseem clover and barley, respectively. At the time of sampling, 10 guarded plants were completely pulled out from each plot with soil surrounding the roots and transferred to the lab for the analyses.

\section{Plant analyses:}

Roots of plant samples were thoroughly, yet carefully, washed under a running water stream to get rid of the surrounding soil, then shoot system was separated from the root system using sheers. After recording the shoot fresh weight of the individual plants, shoots were dried at $70^{\circ} \mathrm{C}$ for 48 hours and shoot dry weight was determined $\left(\mathrm{g} \mathrm{plant}^{-1}\right)$. Dried shoots were, then, ground and wet digested to determine the concentration of total nitrogen according to Bremner and Mulvaney (1982). Phosphorus concentration in the shoot was colorimetrically determined using spectrophotometer as described by Murphy and Riley (1962). The uptake of nitrogen and phosphorus in the shoots $\left(\mathrm{g} \mathrm{plant}^{-1}\right)$ was also calculated by multiplying the shoot dry weight $\left(\mathrm{g}_{\mathrm{g}}\right.$ plant $\left.^{-1}\right)$ by the concentration of each element (\%). The staining method developed by Phillips and Hayman (1970) was used for preparing the root samples for microscopic observation, then the gridlines intersect method of Giovannetti and Mosse (1980) was used to estimate the mycorrhizal infection in the roots $(\%)$.

\section{Statistical analyses:}

Data from both growing seasons, for each trial, were tested for homogeneity of variance after Winer (1971), and no significant differences were detected for the error of the variance between the two growing seasons. Therefore, data from 2012 and 2013 were presented in a combined analysis. Analysis of variance for the effects of organic fertilizer treatments on the investigated parameters (P) for both crops was done using Proc Mixed of SAS 9.1 (SAS Institute, Inc., 2000), according to the following RCBD model:

$$
P_{i j}=\mu+F_{i}+B_{j}+e_{i j}
$$

Where $\mu$ is the overall mean, $F_{i}$ is the organic fertilizer's effect $(i=1,2,3), \mathrm{B}_{j}$ is the block's effect $(j=$ $1,2,3), \mathrm{e}_{i j}$ is the experimental error.

The least significant difference (L.S.D.) procedure was used for means comparison, and significance was declared at $P<0.05$.

\section{RESULTS AND DISCUSSION}

Analysis of variance revealed significant variations among the three tested organic fertilizer treatments for all the studied parameters of both crops $(P<0.001)$, except the mycorrhizal infection, that was not significantly affected by the organic fertilization.

\section{Shoot fresh and dry weights:}

Shoot fresh and dry weights $\left(\mathrm{g} \mathrm{plant}^{-1}\right)$ of barley and berseem clover plants were significantly affected by the type of applied organic fertilizer. Results presented in Table (3) clarify that the compost application produced the highest significant shoot fresh and dry weights for barley, amounting to 99.67 and $17.37\left(\mathrm{~g} \mathrm{plant}^{-1}\right)$, respectively. On the other hand, the highest significant shoot fresh and dry weights for berseem clover were achieved when fertilizing with poultry litter, reaching 2.5 and $0.27\left(\mathrm{~g} \mathrm{plant}^{-1}\right)$, respectively. Compared to the control treatment, the increase in the studied parameters that accompanied the application of organic fertilizers 
reached 35 and $48 \%$ for barley shoot fresh and dry weights, respectively, and 40 and $52 \%$ for berseem clover shoot fresh and dry weights, respectively.

This observed effect of organic fertilizer treatments on fresh and dry weights of the investigated crops might be attributed to the ability of organic fertilizers to provide plants with different nutrients, and cause an improvement of soil water holding capacity, which led to an encouragement in vegetative growth of the tested cultivars (Ramadan, 2013). The superiority of composted manure over poultry litter on fresh and dry weights of barley might be due to the balanced and gradual release of plant nutrients and increased nutrient uptake from composted manure more than poultry litter, which undoubtedly supported the vegetative growth of barley plants. This result was supported by the findings of Ofosu-Anim and Leitch (2009), who studied the relative efficacy of manures coming from different animal sources and composted manures on spring barley production, their results showed that composted manure application significantly increased plant height, chlorophyll content of leaves, dry matter accumulation and nutrient uptake by plants. On the other hand, poultry litter proved to be more effective in case of berseem clover. Berseem clover, as a principle leguminous forage crop, relies mainly on the symbioses with Rhizobium, which is considered the cheapest and usually more effective agronomic practice for ensuring an adequate supply of $\mathrm{N}$ for leguminous forage crops and pastures than the application of nitrogenous fertilizers (Zahran, 1999). The ability of poultry litter to enhance the existence and survival of inoculated nitrogen fixing bacteria in the rhizosphere of the berseem clover, might explain its positive effect on the clover's shoot's fresh and dry matter accumulation. This explanation is supported by the investigations of Kaur et al. (2008) who studied the impact of organic fertilizers with and without chemical fertilizers on soil chemical properties and the establishment of nitrogen fixing bacteria in the rhizosphere of wheat and berseem clover. They found that the number of $R$. leguminosarum biovar trifolii and A. chroococcum were larger in soils receiving poultry manure alone or in combination with inorganic fertilizers compared to soils receiving only inorganic fertilizers. Thus, continuous use of organic amendments can be helpful in increasing the survival and persistence of inoculated nitrogen fixing bacteria in the rhizosphere. This is mainly due to improvements in the soil's chemical properties, particularly organic matter. Changes in soil physical properties such as bulk density and water holding capacity in response to organic fertilizers cannot be ruled out either. Such physicochemical changes are beneficial to low input agriculture; particularly organic farming where the potential of nitrogen-fixing bacteria and other beneficial soil microbes can be harnessed to meet some of the crops requirements (Drinkwater et al., 1995).

\section{Phosphorus concentration and uptake:}

Phosphorus concentration and uptake of barley and berseem clover as affected by organic fertilizer treatments were presented in Table (4). Phosphorus concentration increased from $0.22 \%$ when no fertilizer was applied to $0.36 \%$ with the application of compost. Similarly, $\mathrm{P}$ uptake reached $6.25\left(\mathrm{~g} \mathrm{plant}^{-1}\right)$ when fertilized with compost, against only $1.98\left(\mathrm{~g} \mathrm{plant}^{-1}\right)$ for the control treatment. It was clear that the compost was the most efficient organic fertilizer treatment in significantly increasing $\mathrm{P}$ uptake by barley, compared to poultry manure and control treatments. The amount of increase in $\mathrm{P}$ uptake with compost application reached 36 and $68 \%$ when compared to poultry litter and control treatments, respectively. In case of berseem clover, $\mathrm{P}$ uptake was $36 \%$ higher in the plants fertilized with poultry litter, than in those fertilized with compost, despite there was no significant difference in $\mathrm{P}$ concentration between the two organic fertilizer treatments. The increased uptake of $\mathrm{P}$ by barley and berseem clover plants grown in soil amended with organic fertilizers compared to the untreated plants was compatible with the findings of Zhang et al. (2009), who stated that $\mathrm{P}$ occurs in animal manure in a combination of inorganic and organic forms with the inorganic comprising 45 to $70 \%$ of manure $\mathrm{P}$, while the organic $\mathrm{P}$ constitutes the rest of total $\mathrm{P}$. Inorganic $\mathrm{P}$ is usually present as orthophosphate, which is the form taken up by growing plants and much of the organic $\mathrm{P}$ is easily decomposable by soil microorganisms to the inorganic form. The findings of Leytem et al., (2006) interpreted well the capacity of composted manure to increase barley $\mathrm{P}$ uptake over poultry litter, even though the later was the most efficient in increasing berseem clover $\mathrm{P}$ content. They concluded that, soluble $\mathrm{P}$ release from manure/compost amended soils varies considerably depending on the source of the manure/compost applied (i.e., animal species, diets fed, manure handling and storage). This is primarily due to differences in the concentrations of total and soluble $\mathrm{P}$ in the manure/compost, but may also in part be due to variability in other manure/compost physical and chemical properties. Inorganic phosphate is relatively soluble in soils compared to phytate (an organic $\mathrm{P}$ component of some manures), which is strongly retained and unlikely to be lost as soluble phosphorus. When a variety of materials 
Table 3. Means of shoot fresh and dry weights $\left(\mathrm{g} \mathrm{plant}^{-1}\right)$ of barley and berseem clover as affected by the organic fertilizer treatment, combined for the two growing seasons

\begin{tabular}{lcccc}
\hline \multirow{2}{*}{ Fertilizer treatment } & \multicolumn{2}{c}{ Barley } & \multicolumn{2}{c}{ Berseem clover } \\
\cline { 2 - 5 } & Fresh Weight & Dry Weight & Fresh Weight & Dry Weight \\
\hline Control & $64.42 \mathrm{c}^{*}$ & $9.02 \mathrm{c}$ & $1.50 \mathrm{c}$ & $0.13 \mathrm{c}$ \\
\hline Compost & $99.67 \mathrm{a}$ & $17.37 \mathrm{a}$ & $1.90 \mathrm{~b}$ & $0.21 \mathrm{~b}$ \\
\hline Poultry litter & $84.96 \mathrm{~b}$ & $14.26 \mathrm{~b}$ & $2.50 \mathrm{a}$ & $0.27 \mathrm{a}$ \\
\hline
\end{tabular}

* Means followed by the same small letter within the same column are not significantly different at 0.05 level of probability.

Table 4. Means of phosphorous concentration $(\%)$ and uptake $\left(\mathrm{g} \mathrm{plant}^{-1}\right)$ of barley and berseem clover as affected by the organic fertilizer treatment, combined for the two growing seasons

\begin{tabular}{lcccc}
\hline \multirow{2}{*}{ Fertilizer treatment } & \multicolumn{2}{c}{ Barley } & \multicolumn{2}{c}{ Berseem clover } \\
\cline { 2 - 5 } & P Concentration & P Uptake & P Concentration & P Uptake \\
\hline Control & $0.22 \mathrm{c}^{*}$ & $1.98 \mathrm{c}$ & $0.16 \mathrm{~b}$ & $0.02 \mathrm{c}$ \\
Compost & $0.36 \mathrm{a}$ & $6.25 \mathrm{a}$ & $0.26 \mathrm{a}$ & $0.05 \mathrm{~b}$ \\
Poultry litter & $0.28 \mathrm{~b}$ & $3.98 \mathrm{~b}$ & $0.28 \mathrm{a}$ & $0.08 \mathrm{a}$ \\
\hline
\end{tabular}

* Means followed by the same small letter within the same column are not significantly different at 0.05 level of probability.

Table 5. Means of nitrogen concentration (\%) and uptake $\left(\mathrm{g} \mathrm{plant}^{-1}\right)$ of barley and berseem clover as affected by the organic fertilizer treatment, combined for the two growing seasons

\begin{tabular}{lcccc}
\hline \multirow{2}{*}{ Fertilizer treatment } & \multicolumn{2}{c}{ Barley } & \multicolumn{2}{c}{ Berseem clover } \\
\cline { 2 - 5 } & N Concentration & N Uptake & N Concentration & N Uptake \\
\hline Control & $2.07 \mathrm{a}^{*}$ & $18.66 \mathrm{c}$ & $2.83 \mathrm{~b}$ & $0.37 \mathrm{c}$ \\
Compost & $2.05 \mathrm{~b}$ & $35.61 \mathrm{a}$ & $3.17 \mathrm{a}$ & $0.66 \mathrm{~b}$ \\
Poultry litter & $2.06 \mathrm{ab}$ & $29.36 \mathrm{~b}$ & $3.17 \mathrm{a}$ & $0.84 \mathrm{a}$ \\
\hline
\end{tabular}

* Means followed by the same small letter(s) within the same column are not significantly different at 0.05 level of probability.

(swine, dairy, and beef cattle manures having been handled/stored differently) with a range of phytate content (ranging from 0 to $8 \%$ of the total $\mathrm{P}$ ) were incorporated into soils, there was no significant correlation between phytate content and soil P solubility (Leytem and Westermann, 2005; Leytem et al., 2005). In this instance the small amounts of phytate in the manures were probably insufficient to influence phosphorus solubility in the soil. Instead, phosphorus solubility was clearly influenced by the amount of C added with the manures. On the other hand, when poultry manures with a large range of phytate content (35-80\% of the total P) were added to a similar soil, the amount of phytate in the manures was strongly negatively correlated with the bicarbonate extractable phosphate concentration following manure application (Leytem et al., 2006). This relationship between manure phytate and phosphorus solubility was transient, becoming insignificant after nine weeks of incubation. These findings elucidate clearly that when, in the current study, composted manure was applied to barley plants, the proportion of phytate and, therefore, water-soluble phosphate, had a strong influence on the solubility of the manure phosphorus soon after application and that was compatible with $\mathrm{P}$ uptake of barley plants that was harvested 45 days after sowing. On the other hand, poultry litter with high phytate content was applied to berseem clover, that was harvested 55 days after planting and although phytate is strongly bound in soils, microbes in the soil were able to easily break it down into inorganic phosphate within few weeks, increasing soil P solubility to that of manures having low phytate concentrations, which in turn have led to the increased $\mathrm{P}$ uptake of berseem clover plants treated with poultry litter over the plants treated with composted manure.

\section{Nitrogen concentration and uptake:}

Nitrogen concentration in a forage crop is the primary indicator of its crude protein content, which is a very important determinant of forage quality (Assefa and Ledin, 2001; Lithourgidis et al., 2006). Means presented in Table(5) reveal that, nitrogen concentration of barley and berseem clover was significantly influenced by the two applied organic amendments. Despite the statistical significance, variations between the two organic fertilizer treatments and the control treatments in case of barley $\mathrm{N}$ concentration were neglectable. However, clear variations were detected in the $\mathrm{N}$ uptake by barley plants, where $\mathrm{N}$ uptake by plants 
fertilized with compost was 18 and $48 \%$ higher than $\mathrm{N}$ uptake under poultry litter or no fertilization, respectively. No variations between the compost and poultry litter application was achieved in case of $\mathrm{N}$ concentration in berseem clover. On the contrary, $\mathrm{N}$ uptake in berseem clover varied significantly with type of applied organic fertilizer, with the highest amount of $\mathrm{N}$ uptake reached $0.84\left(\mathrm{~g}\right.$ plant $\left.^{-1}\right)$ with poultry litter. The current results were in general agreement with those obtained by Ofosu-Anim and Leitch (2009), who reported significant variations in $\mathrm{N}$ mineralization among different organic manure sources. They reported that, among the tested organic manures, compost and sheep manure recorded the highest and lowest significant $\mathrm{N}$ mineralization, respectively. Analysis of plant tissues, in the same experiment, revealed an increase in total $\mathrm{N}$ content, amounting to 1.4-fold, 2.6fold, and 2.6-fold, in average at four, eight, and twelve weeks after germination, respectively. A significant increase in yield and dry matter production was also observed under organic manure applications. Researchers attributed the difference in $\mathrm{N}$ uptake among the studied organic treatments to the variation in cumulative inorganic $\mathrm{N}$ mineralized $\left(\mathrm{NH}_{4}-\mathrm{N}+\mathrm{NO}_{3}-\mathrm{N}\right)$ from the different types of organic manure. In general, they reported that the fast decomposition of the easily altered organic $\mathrm{N}$, may be the reason behind the high amounts of $\mathrm{NH}_{4}-\mathrm{N}$ at the early incubation stages. They attributed this observation to the conversion of $\mathrm{NH}_{4}-\mathrm{N}$ to $\mathrm{NO}_{3}-\mathrm{N}$ and possibly losses through volatilization. By extending the incubation period, a decrease in mineralization was observed, and may be attributed to the disappearance of easily altered $\mathrm{N}$ and the dominance of the more resistant organic N (Sierra, 1990). In their 3year study, Miller et al. (2004) examined the impact of three application rates of composted or fresh manure containing straw or wood-chip bedding on dry matter yield, uptake, and soil nutrients of barley. Their results indicated that application of composted manure resulted in similar DM yields to fresh manure, and that application of fresh or composted manure containing wood bedding resulted in similar DM yields to manure containing straw bedding. They found that application rate of the organic amendments was the most important variable that have significantly affected all crop and soil parameters by its interaction with type, bedding, and year, indicating a strong influence on crop yield, nutrient uptake, and nutrients in the soil. Sharifi et al. (2014) extended the three-year study initiated earlier by Miller et al. (2004) to an eight-year study in order to investigate the effects of the long-term application of fresh versus composted beef manure to barley on potentially mineralizable nitrogen, and mineralizable nitrogen pools. They found that the medium and high rates of organic amendment resulted in increases in potentially, readily and intermediate mineralizable $\mathrm{N}$ pools in ranges of 140-355 \% compared with the average of the inorganic fertilizers and control treatments. A linear increase in soil mineralizable $\mathrm{N}$ pools was observed after eight years of organic amendment application. They confirmed also, that manure decomposition stage (Fresh Manure < Composted Manure) and application rates (Low < Medium < High) were the dominant factors affecting quantity of active soil organic $\mathrm{N}$ fraction. Greater quantity of readily available and intermediate mineralizable $\mathrm{N}$ was achieved with application of fresh manure and use of straw bedding, compared with composted manure and wood-chip bedding. On the other hand, composted manure contributed more to the intermediate and stable mineralizable $\mathrm{N}$ pools and consequently was more effective in accumulating organic $\mathrm{N}$ in soil. Poultry manure was more efficient than composted manure in increasing the nitrogen uptake of berseem clover.

Table 6. Means of root mycorrhizal infection (\%) of barley and berseem clover as affected by the organic fertilizer treatment, combined for the two growing seasons

\begin{tabular}{lll}
\hline Fertilizer & \multicolumn{2}{c}{ Mycorrhizal infection } \\
\cline { 2 - 3 } treatment & Barley & Berseem clover \\
\hline Control & $35.25 \mathrm{a}^{*}$ & $37.94 \mathrm{a}$ \\
Compost & $36.61 \mathrm{a}$ & $38.58 \mathrm{a}$ \\
Poultry litter & $35.93 \mathrm{a}$ & $35.13 \mathrm{a}$ \\
\hline
\end{tabular}

* Means followed by the same small letter within the same column are not significantly different at 0.05 level of probability.

\section{Mycorrhizal infection:}

The application of both organic treatments didn't show any potential to significantly increase the mycorrhizal infection percentage in barley and berseem clover roots (Table 6). In line with the current study, Scullion et al. (1998) reported that, even after several years of organic fertilizers application, the organic farming system may fail to develop an effective mycorrhizal community. They attributed this to the management practices that are unfavourable to mycorrhizal development. For example, the frequent application of $\mathrm{P}$ fertilizers in the organic farming system, may lead to the accumulation of high $\mathrm{P}$ concentrations in the soil (Dekkers and van der Werff, 2001). In addition, unfavorable soil conditions, especially moisture and temperature, or the occurrence of plant disease, can also prevent the mycorrhizal community development (Ryan and Graham, 2002). 
Moreover, the development of an effective mycorrhizal community could also be hindered by the cultural practices that are often used to control undesirable weeds, like excessive tillage, in addition to the frequent cultivation of non-mycorrhizal crops. Another reason for the poor performance of AM in some organic farming systems is the minimal response of some modern crop cultivars to mycorrhiza, which make them receive little benefit from its presence, even though good colonization with effective mycorrhiza may be detected (Hetrick $e t$ al., 1996 and Aguilera- Gomez et al., 1998). Researchers reported significant variations in the response of old and modern crop cultivars to mycorrhizal association (Stoppler et al., 1990; Hetrick et al., 1993, 1996). Nonetheless, the fact that the host crop might be receiving benefits from the mycorrhizal association other than those being measured, might stand behind the apparent lack of benefit. On the other hand, better mycorrhizal colonization, associated with higher diversity and higher propagule numbers, was reported by many researchers in organic farming systems. Therefore, there is still a pressing need to further investigate the influence of AM fungi to the functioning of organic agroecosystems and in particular to crop performance. It is believed that AM fungi are capable of compensating for lower inputs of $\mathrm{P}$ fertilizer in organic farming systems. Kahiluoto and Vestberg (1998) stated that, the positive effect of AM fungi in increasing $\mathrm{P}$ availability for the grown crop in the organic farming system, is similar to the positive effect of superphosphate application in the conventional farming system. However, this might not always be reflected in the form of higher yields even when phosphorus use efficiency is high (Galvez et al., 2001). The insignificant effect of the used organic treatments on the percentage of mycorrhizal infection in the roots of both barley and berseem clover could be attributed to the high $\mathrm{P}$ content of the compost and poultry litter, which in turn raised the available $\mathrm{P}$ concentration in soil leading to poor performance of mycorrhiza fungi (Gosling et al. 2006).

\section{CONCLUSION}

A clear effect of the application of compost and poultry litter on the nutritional status of barley and berseem clover was detected under the organic farming system. The two tested forage crops responded differently to the applied organic amendments. Generally, the best barley shoot fresh and dry weights, as well as nutrients' uptake and concentrations were achieved with compost application. On the other hand, berseem clover performed better when fertilized with poultry litter and produced the highest shoot fresh and dry weights and nutrients uptake and concentration.
Although root mycorrhizal infection was detected in both crops, that were organically fertilized, its percentage didn't vary significantly among the tested organic amendments. The current results suggest that, under the organic farming system, fertilizing barley with compost and berseem clover with poultry litter would improve yield and quality of the end fodder through improving the nutrients uptake and concentration in the plants.

\section{ACKNOWLEDGMENTS}

The authors are grateful to Dr. Ibrahim Abouleish, and Mrs. Angela Hofmann at SEKEM-Egypt for providing the experimental site in one of their organic farms, also for their assistance during running the field trials.

\section{REFERENCES}

Aguilera-Gomez, L.I., P. Ramirez-Moreles, J.T. FriasHernandez, A. Chapa- Elizondo, V. Olalde-Portugal (1998). Influence of Glomus fasciculatum on physiology and growth of three kinds of maize. Phyton (Int. J. Exp. Bot.) 62:101-107.

Alazmani, A. (2014). Effect of nitrogen fertilizer on feed and grain yield of barley cultivar. Intl. Res. J. Appl. Basic Sci. 8:2013-2015.

Assefa, G., and I. Ledin (2001) Effect of variety, soil type and fertilizer on the establishment, growth, forage yield, quality and voluntary intake by cattle of oats and vetches cultivated in pure stands and mixtures. Anim. Feed Sci. Technol. 92:95-111.

Bremner, J.M. and C.S. Mulvaney (1982). Nitrogen-Total. In Methods of soil analysis. Part 2. $2^{\text {nd }}$ ed. Agronomy 9:595624.

Bagyaraj, D.J. (1992). Vesicular-arbuscular mycorrhiza: Application in agriculture. Methods in Microbiology 24:359-374.

Bonfante-Fasolo, P. (1987). Vesicular arbuscular mycorrhizae fungus plant interactions at the cellular level. Symbiosis 3:249-254.

Dekkers, T.B.M. and P.A. van der Werff (2001). Mutualistic functioning of indigenous arbuscular mycorrhizae in spring barley and winter wheat after cessation of long-term phosphate fertilization. Mycorrhiza 10:195-201.

De Santis, G., A. Lannucci, D. Dantone and E. Chiaravalle (2004). Changes during growth in the nutritive value of components of berseem clover (Trifolium alexandrinum L.) under different cutting treatments in a Mediterranean region. Grass Forage Sci. 59:378-388.

Drinkwater, L.E., D.K. Letourneau, F. Worknehm, A.H.C. Van Bruggen and C. Shennan (1995). Fundamental differences between conventional and organic tomato agroecosystems in California. Ecological Applications 5:1098-1112.

Edmeades, D.C. (2003). The long-term effects of manures and fertilisers on soil productivity and quality: a review. Nutr. Cycl. Agroecosyst. 66:165-180. 
Galvez, L., D.D. Douds Jr., L.E. Drinkwater, P. Wagoner (2001). Effect of tillage and farming system upon VAM fungus populations and mycorrhizas and nutrient uptake of maize. Plant and Soil 118:299-308.

Giovannetti, M., and B. Mosse (1980). An evaluation of techniques of measuring vascular mycorrhizae infection in roots. New Phytologist 84:489-500.

Giovanni, A., C. Giovanni, R. Emanuela, and M. Pasquale (2011). Effect of manure vs. fertilizer inputs on productivity of forage crop models. Int. J. Environ. Res. Public Health 8:1893-1913.

Gosling, P., A. Hodge, G. Goodlass, G.D. Bending (2006). Arbuscular mycorrhizal fungi and organic farming. Agriculture, Ecosystems and Environment 113:17-35.

Gupta, M.K. (2007). Handbook of Organic farming and Biofertilizers. ABD Publishers.

Hetrick, B.A.D., G.W.T. Wilson, T.S. Cox (1993). Mycorrhizal dependence of modern wheat cultivars and ancestors - a synthesis. Canad. J. Bot. 71:512-518.

Hetrick, B.A.D., G.W.T. Wilson, T.C. Todd (1996). Mycorrhizal response in wheat cultivars, relationship to phosphorus. Canad. J. Bot. 74:19-25.

Kahiluoto, H. and M. Vestberg (1998). The effect of arbuscular mycorrhiza on biomass production and phosphorus uptake from sparingly soluble sources by leek (Allium porrum L.) in Finnish field soils. Biol. Agric. Hortic. 16:65-85.

Kaur, K., G. Sneh, and K.K. Krishan (2008). Impact of Organic Fertilizers with and without Chemical Fertilizers on Soil Chemical Properties and the Establishment of Nitrogen-Fixing Bacteria in the Rhizosphere. Microbes Environ. 23:313-316.

Kingery, W.L., C.W. Wood, D.P. Delaney, J.C. Williams, G.L. Mullins and E. van Santen (1993). Implications of long-term land application of poultry litter on tall fescue pastures. J. Prod. Agric. 6:390-395.

Leytem, A.B., D.R. Smith, T.J. Applegate, and P.A. Thacker (2006). The influence of manure phytic acid on phosphorus solubility in calcareous soils. Soil Sci. Soc. Amer. J. 70:1629-1638.

Leytem, A.B. and D.T. Westermann (2005). Phosphorus availability to barley from manures and fertilizers on a calcareous soil. Soil Sci. 170:401-412.

Leytem, A.B., B.L. Turner, V. Raboy and K. Peterson (2005). Linking manure properties to soil phosphorus solubility: Importance of the carbon to phosphorus ratio. Soil Sci. Soc. Amer. J. 69:1516-1524.

Lithourgidis, A.S., I.B. Vasilakoglou, K.V. Dhima, C.A. Dordas and M.D. Yiakoulaki (2006) Forage yield and quality of common vetch mixtures with oat and triticale in two seeding ratios. Field Crop Res. 99:106-113.

Lithourgidis, A.S., T. Matsi, N. Barbayiannis and C.A. Dordas (2007). Effect of liquid cattle manure on corn yield, composition and soil properties. Agron. J. 99:1041-1047.
Lynch, D.H., R.P. Voroney and P.R. Warman (2005). Soil physical properties and organic matter fractions under forages receiving composts, manure or forages. Compost Sci. Util. 13:252-261.

Lucero, D.W., D.C. Martens, J.R. McKenna and D.E. Starner (1995). Poultry litter effects on unmanaged pasture yield, nitrogen and phosphorus uptakes, and botanical composition. Commun. Soil Sci. Plant Anal. 26:861-881.

Mezni, M., S. Haffani, N. Khamassi and A. Albouchi (2013). Effects of the defoliation height on the growth, mineral uptake and soluble carbohydrate contents in berseem clover (Trifolium alexandrinum L.) var. Khadhraoui. J. Agric. Vet. Sci. 2:78-91.

Mezni, M. et B. Sifi (1995). Réponses des Medicago annuels à l'inoculation dans le semi-aride Tunisien. In Drevon J.J. (éd.). «Facteurs limitant la fixation symbiotique de l'azote dans le bassin méditerranéen». Les Colloques 77:291-297.

Miller, J.J., B.W. Beasley, F.J. Larney and B.M. Olson (2004). Barley dry matter yield, crop uptake, and soil nutrients under fresh and composted manure containing straw or wood-chip bedding. Canad. J. Plant Sci. 84:987-999.

Muir, J.P., S.R. Stokes and E.P. Prostko (2001). The effect of dairy compost on summer annual dicots grown as alternative silages. Prof. Anim. Sci. 17:95-100.

Murphy, J. and J.P. Riley (1962). A modified single solution method for the determination of phosphate in natural waters. Analytica Chimica Acta 27:31 -36.

Newton, G.L., J.K. Bernard, R.K. Hubbard, J.R. Allison, R.R. Lowrance, G.J. Gascho, R.N. Gates and G. Vellidis (2003). Managing manure nutrients through multi-crop forage production. J. Dairy Sci. 86:2243-2252.

Oehl, F., E. Sieverding, P. Maeder, D. Dubois, K. Ineichen, T. Boller and A. Wiemken (2004). Impact of long-term conventional and organic farming on the diversity of arbuscular mycorrhizal fungi. Ecosystem Ecology 138:574-583.

Ofosu-Anim, J. and M. Leitch (2009). Relative efficacy of organic manures in spring barley (Hordeum vulgare L.) production. Aust. J. Crop Sci. 3:13-19.

Phillips J.M. and D.S. Hayman (1970). Improved procedures for clearing and staining parasitic and vesiculararbuscular mycorrhizae fungi for rapid assessment of infection. Trans. Br. Mycol. Soc. 55:158- 161.

Ramadan, A. (2013). Role of potassium additions, organic manure and effective microorganisms (EM) on strawberry production in sandy soils. M.Sc. Thesis, Mansoura University, Egypt.

Ryan, M.H. and J.H. Graham (2002). Is there a role for arbuscular mycorrhizal fungi in production agriculture? Plant and Soil 244:263-271.

Salama, H.S.A. (2015). Interactive effect of forage mixing rates and organic fertilizers on the yield and nutritive value of berseem clover (Trifolium alexandrinum L.) and annual ryegrass (Lolium multiflorum Lam.). Agric. Sci. 6:415-425. 
SAS Institute, Inc. (2000). SAS/STAT User's Guide, Version 9.1 SAS Institute, Cary, NC.

Scullion, J., W.R. Eason and E.P. Scott (1998). The effectivity of arbuscular mycorrhizal fungi from high input conventional and organic grassland and grass-arable rotations. Plant and Soil 204:243-254.

Sharifi, M., B.J. Zebarth, J.J. Miller, D.L. Burton and A.C. Grant (2014). Soil nitrogen mineralization in a soil with long-term history of fresh and composted manure containing straw or wood-chip bedding. Nutr. Cycl. Agroecosyst. 99:63-78.

Sierra, J. (1990). Analysis of soil nitrogen mineralization as estimated by exponential models. Soil Biol. Biochem. 22:1151-1153.

Stoppler, H., E. Kolsch and H. Vogtmann (1990). Vesiculararbuscular mycorrhiza in varieties of winter-wheat in a low external input system. Biol. Agric. Hortic. 7:191-199.
Tessem, Z.K., J. Mihret and M. Solomon (2010). Effect of defoliation frequency and cutting height on growth, drymatter yield and nutritive value of Napier grass (Pennisetum purpureum (L.) Schumach). Grass Forage Sci. 65:421-430.

Trivedi, P.C. (2007). Organic Farming and Mycorrhizae in Agriculture. I.K. International Publishing House Pvt. Ltd.

Winer, B.J. (1971). Statistical principles in experimental design. $2^{\text {nd }}$ Edition. McGraw-Hill Kogakusha, LTD.

Zahran, H. (1999). Rhizobium-Legume Symbiosis and Nitrogen Fixation under Severe Conditions and in an Arid Climate. Microbiol. Mol. Biol. Rev. 63:968-989.

Zhang, H., M. Xu and F. Zhang (2009). Long-term effects of manure application on grain yield under different cropping system and ecological conditions in China. J. Agr. Sci. 147:31-42.

\section{الملخص العربي}

\section{الحالة الغذائية والإصابة بالميكوريزا المتوطنة للبرسيم المصري والثعير عند التسميد بفرشة الاواجن والكمبوست تحت نظام الزراعة العضوية$$
\text { هاله حسن بدرى، هبه صبرى عطيه سلامه، احمد رمضان }
$$

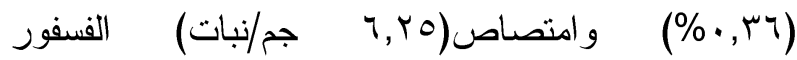

وامتصاص النيتزوجين(1)

بفرشة الدو اجن وعدم التسميد. على الجانب الاخر، اعطى

البرسيم المصرى اعلى وزن رطب(r,o r جم/نبات) وجاف

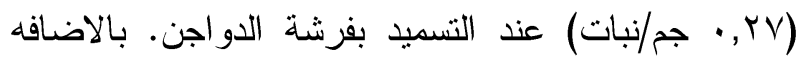

الى ذلك، تحسن امتصاص الفسفور(^ •, • جم/نبات)

و النيتزوجين (عر, · جم/نبات) بواسطة البرسيم المصرى

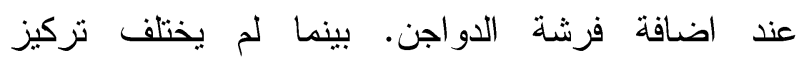

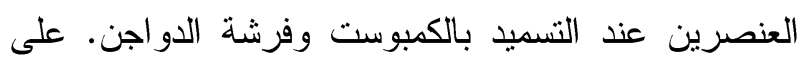

الرغم من وجود اصابة بفطر الميكوريز ا فى جذور الثعير

و البرسيم المصرى، مع التسميد العضوى، الا ان نسبة

الاصابة لم تختلف معنويا باختلاف نوع التسميد. ترجح

النتائج الحالية انة، تحت ظروف الزر اعة العضوية، تسميد

الثعير بالكمبوست و البرسيم المصرى بفرشة الدو اجن يمكن

ان يؤدى الى تحسن فى محصول وجودة العلف الناتج عن

طريق تحسين تزكيز و امتصاص العناصر الغذائية بواسطة
تعتبر الزراعة العضوية من النظم الزراعية متزايدة

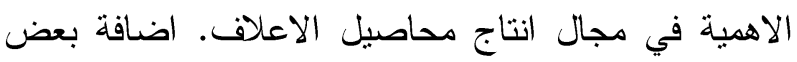

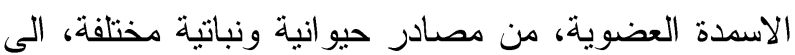

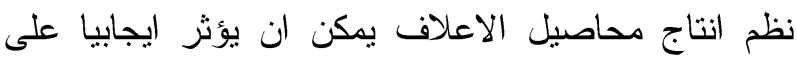
انتاجية و جودة المحصول عن طريق تحسين الحالة الغذائية للنبات. تم اجراء التجارب الحقلية خلال الموسم الشتوى جود

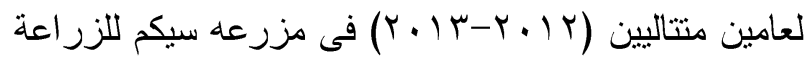
العضوية. كان الهدف من التجارب هو دراسة تاثير التسميد بالكمبوست وفرشة الدواجن على الوزن الرطب و الجاف للمجموع الخضرى(جم/نبات)، نسبة(\%) وامتصاص (جم/نبات) النيتزوجين و الفسفور للبرسيم المصرى و الشعير . بالاضافة الى دراسة التباين فى اصنابة الجذور بفر الميكوريز ا تحت ظروف الزر اعة العضوية. اظهرت النتائج اختلافات معنوية فى استجابة المحصولين للاسمدة العضوية المختبره. اعطى الشعير اعلى وزن رطب(

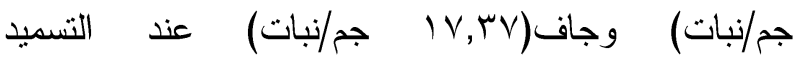
بالكمبوست. كما ادت اضافة الكمبوست الى تحسين تركيز 